\title{
Perbedaan Berbagai Konsentrasi Ekstrak Daun Jeruk Nipis (Citrus aurantifolia) Dalam Bentuk Lilin Aromatik terhadap Jumlah Lalat Rumah (Musca Domestica) yang Tertolak
}

\author{
Wulandari Rika ${ }^{1}$ dan Mimin Karmini ${ }^{1}$ \\ 1Jurusan Kesehatan Lingkungan Poltekkes Kemenkes Bandung \\ E-mail : ikawulan.wulandari@yahoo.co.id
}

\begin{abstract}
ABSTRAK : Lalat rumah merupakan salah satu vektor penyakit yang dapat membawa beberapa jenis bakteri patogen pada manusia, diantaranya typoid, kolera, disentri, dan cacingan, sehingga perlu dilakukan upaya pengendaliannya dengan insektisida nabati daun jeruk nipis (Citrus aurantifolia) berbentuk lilin aromatik. Penelitian ini bertujuan untuk mengetahui perbedaan berbagai konsentrasi ekstrak daun jeruk nipis (Citrus aurantifolia) dalam bentuk lilin aromatik terhadap jumlah lalat rumah (Musca domestica) yang tertolak, dengan konsentrasi $0,4 \%, 0,6 \%, 0,8 \%$, dan kontrol yang tidak menggunakan ekstrak daun jeruk nipis. Jenis penelitian ini adalah eksperimen, sampel dalam penelitian ini adalah lalat musca domestica sebanyak 525 ekor, dengan jumlah pengulangan 6 kali dan perlakuan 3 buah, masing-masing perlakuan berisi 25 ekor lalat pada kandang, teknik pengambilan sampel secara random sampling, dan teknik pengumpulan data dengan menghitung presentase jumlah lalat yang tertolak serta mengukur suhu dan kelembaban udara ruangan, lama pengamatan 60 menit yang diamati setiap menit. Hasil Penelitian menunjukan bahwa presentase jumlah lalat rumah yang tertolak pada masing-masing konsentrasi ekstrak daun jeruk nipis yaitu pada konsentrasi $0,4 \%$ sebesar $81,98 \%$, pada konsentrasi $0,6 \%$ sebesar $86,43 \%$, dan pada konsentrasi $0,8 \%$ sebesar $92,82 \%$. Hasil uji statistik Kruskal-Wallis diperoleh $p \leq \alpha(0,045$ $\leq 0,05$ ) sehingga ada perbedaan konsentrasi ekstrak daun jeruk nipis (Citrus aurantifolia) dalam bentuk lilin aromatik terhadap jumlah lalat rumah (Musca domestica) yang tertolak. Disarankan masyarakat menggunakan ekstrak daun jeruk nipis dalam bentuk lilik aromatik untuk menolak kehadiran lalat rumah, terutama di warung-warung makan.
\end{abstract}

Kata Kunci : Ekstrak daun jeruk nipis (Citrus aurantifolia), lalat rumah (Musca domestica), lilin aromatik, tertolak (repellent)

ABSTRACT : House fly is one of diseases vector that can bring some pathogens bacteria to human such as typoid, cholera, dysentery, and wormy, so it is necessary to control its efforts with citrus leaves (Citrus aurantifolia) vegetable leaf insecticide into aromatic candle. This study aims to determine the difference of various concentration of citrus leaves extract (Citrus aurantifolia) into aromatic candle to the number of house flies (Musca domestica) rejected, with concentrations of $0,4 \%, 0,6 \%, 0,8 \%$, and control. This research type is experiment, samples were musca domestica flies as much as 525 flies, with 6 replications and 3 treatments, The sampling technique used is random sampling, and data collection techniques with calculated the percentage of the number of flies rejected and measured the temperature and humidity of the room, the observed duration of 60 minutes observed every minute. The percentage of houseflies rejected at concentration $0.4 \%$ is $81.98 \%$, at a concentration $0.6 \%$ is $86.43 \%$, and at a concentration $0.8 \%$ is $92.82 \%$. Kruskal-Wallis statistical test result $p \leq \alpha(0,045 \leq 0,05)$, then there is a difference of citrus leaves extract concentration (Citrus aurantifolia) into aromatic candle to number of house flies (Musca domestica) rejected, it is recommended that community use the citrus leaves (Citrus aurantifolia) into aromatic candle to deny the house flies, especially in street food.

Keywords : citrus leaves extract (citrus aurantifolia), house flies (Musca domestica), aromatic candle, repellent 


\section{PENDAHULUAN}

Lalat rumah (Musca domestica) merupakan lalat yang paling umum dikenal orang karena biasanya lalat ini hidup dekat dengan manusia. Lalat rumah dikenal juga sebagai vektor mekanik pembawa penyakit yang berbahaya bagi kesehatan manusia. Lalat memiliki bulu-bulu halus yang terdapat disekujur tubuhnya yang memungkinkan dapat berperan sebagai vektor penyakit, karena perilaku lalat yang suka berpindah-pindah dari suatu makanan (biasanya bahan organik yang membusuk ataupun kotoran) ke makanan lain, untuk makan dan bertelur. ${ }^{1}$

Organisme yang disebarkan $M$. domestica kurang lebih ada 100 jenis yang bersifat patogen terhadap manusia dan hewan. ${ }^{2}$ Menurut Dirjen P2M \& PL. Depkes RI, 2001 (dalam Khonsa, 2014) jenis penyakit yang diakibatkan oleh lalat diantaranya disentri, diare, thypoid, dan kolera. ${ }^{3}$

Kesenangan lalat yang hinggap disembarang tempat, baik itu tempat bersih maupun tempat kotor, dapat membuat lalat membawa berbagai bakteri patogen pembawa penyakit. Agen penyakit ditularkan dari mulut, feses dan bagian tubuh lainnya yang terkontaminasi dan dipindahkan pada makanan manusia. ${ }^{2}$ Seperti halnya manusia, lalat membutuhkan protein untuk pertumbuhan, perkembangbiakan, dan regenasi sel yang rusak. Hal inilah yang membuatnya begitu tertarik untuk menghinggapi makanan/sisa makanan di atas meja. Sejumlah kasus infeksi telah banyak ditemukan pada makanan jajanan.

Kerugian yang ditimbulkan lalat bukan hanya sebagai vektor mekanis saja, tetapi keberadaannya dalam wilayah pemukiman manusia dianggap sebagai pengganggu kenyamanan. Pada saat populasi meningkat, lalat $M$. domestica dapat menjadi pengganggu baik bagi orang yang sedang bekerja maupun istirahat. Kepadatan lalat yang tinggi ini dapat menimbulkan dampak pada usaha makanan di restoran atau rumah makan, karena memberikan kesan kondisi yang tidak sehat dan tidak nyaman. $^{2}$

Tentu saja keberadaan lalat sangat mengganggu namun sulit untuk dibunuh jika hanya menggunakan tangan kosong, karena lalat merupakan binatang kecil yang agresif yang bisa terbang. Untuk itu diperlukan cara alternatif yang aman adalah dengan menggunakan bahan alami dari tumbuhan sebagai pestisida nabati yang bersifat biodegradable yaitu mudah terurai baik, serta tidak mencemari lingkungan sehingga relatif aman bagi manusia. Kelebihan insektisida nabati yaitu hanya sedikit meninggalkan residu pada lingkungan dan zat aktif dalam insektisida lebih cepat terurai di alam sehingga tidak menimbulkan resistensi pada sasaran. ${ }^{4}$

Tanaman genus Citrus merupakan salah satu tanaman penghasil minyak atsiri yang merupakan suatu substansi alami yang telah dikenal memiliki efek sebagai repelen nyamuk menurut Reni, 2008 (dalam Rina, 2014). Minyak atsiri yang dihasilkan oleh tumbuhan anggota Citrus sp. terdapat pada bagian tanamannya, tidak hanya pada buah, tetapi juga pada daun. ${ }^{4,5}$ Jeruk nipis (Citrus aurantifolia) merupakan salah satu jenis tumbuhan yang termasuk dalam 2400 jenis tumbuhan lain yang mengandung bahan pestisida nabati. $^{6}$

Komponen minyak atsiri dalam daun jeruk nipis (Citrus aurantifolia) adalah $\alpha$-Pinene $(0,68 \%), \quad \beta$-Pinene $(5,70 \%), \quad \rho$-Cymene $(8,58 \%)$, transLinalool oxide $(0,73 \%)$, Linalool $(2,39 \%)$, Fenchol $(1,67 \%)$, Cis-Limonene oxide $(2,29 \%)$, trans-Limonene oxide $(1,05 \%)$, Pinocarveol $\quad(0,58 \%), \quad \beta$-Terpineol $(0,79 \%)$, Borneol $(1,12 \%)$, Terpineol-4 (4,76\%), $\rho$-Cimene-8-ol (1,93\%), dan DLimonen $(28,27 \%)$ dimana komponen 
yang bertindak sebagai repelen yaitu kandungan D-Limonen. ${ }^{6}$

Minyak atsiri dalam daun jeruk nipis dapat dimanfaatkan untuk pembuatan lilin penolak lalat rumah, karena sifat dari minyak atsiri yang mudah menguap dan terbakar. Lilin penolak lalat rumah yang terbuat dari bahan alami ini dapat menjadi alternatif produk penolak lalat rumah, karena sifatnya yang ramah lingkungan, dapat digunakan oleh setiap kalangan masyarakat karena nilai guna yang tinggi, serta aman bagi masyarakat.

Dari hasil penelitian yang dilakukan Kartika dkk (2014), megenai Pemanfaatan Limonen dari Kulit Jeruk Nipis dalam Pembuatan Lilin Aromatik Penolak Serangga didapatkan hasil, $50 \%$ kecoa meninggalkan area yang sudah diberi lilin aromatik dengan penambahan atsiri 0,3\%, 100\% kecoa meninggalkan area yang sudah diberi lilin aromatik dengan penambahan atsiri $0,4 \%$, dan $100 \%$ kecoa meninggalkan area yang telah diberi lilin aromatik dengan penambahan atsiri $0,5 \%{ }^{8}$

Hasil Penelitian Rina, (2014) yang berjudul Efektivitas Ekstrak Daun Jeruk Nipis (Citrus aurantifolia) dalam Membunuh Larva Nyamuk Aedes aegypti, pada konsentrasi $0,40 \%$ terjadi kematian larva 21 ekor (82\%), konsentrasi $0,45 \%$ sebanyak 23 ekor (92\%), konsentrasi $0,50 \%$ sebanyak 24 ekor (96\%), dan konsentrasi 0,55\% sebanyak 25 ekor (100\%). ${ }^{5}$

Kandungan d-limonen pada daun jeruk nipis juga dapat digunakan sebagai repellent nabati penolak nyamuk, dikutip dalam Skipsi Rina Murdani (2014) menyebutkan bahwa hasil penelitian Reni (2008) mengenai Berbagai Macam Daun Jeruk sebagai Repellent didapatkan hasil rata-rata efikasi perasan daun jeruk nipis sebagai penolak nyamuk yaitu $87,97 \% .^{5}$

Pada penelitian ini peneliti ingin membuktikan apakah ekstrak daun jeruk nipis (Citrus aurantifolia) dapat memberikan efek sebagai pengusir lalat rumah (Musca Domestica) dalam bentuk lilin aromatik. Daun jeruk nipis dipilih karena selain mudah didapatkan, kandungan D-Limonen dalam minyak atsirinya lebih besar yaitu 28,27\% merupakan kandungan terbesar yang sifatnya sebagai repelen. ${ }^{6}$ Ekstrak daun dicampurkan ke dalam bentuk lilin, selain lebih dapat diaplikasikan di masyarakat terutama warung makan, aroma dari campuran ekstrak akan menambah poin lain sebagai repelen yang menarik.

Berdasarkan uraian latar belakang tersebut peneliti tertarik untuk melakukan penelitian mengenai "Perbedaan Berbagai Ekstrak Daun Jeruk Nipis (Citrus aurantifolia) Dalam Bentuk Lilin Aromatik Terhadap Jumlah Lalat Rumah (Musca domestica) yang Tertolak".

\section{METODE}

Penelitian ini bersifat eksperimen berskala laboratorium dilakukan pada bulan Mei 2017. Lokasi penelitian di Kampus Jurusan Kesehatan Lingkungan Jalan Babakan Loa, Cimahi Utara dengan sampel lalat Musca domestica diperoleh dari TPS Apartemen Gateway Pasteur Bandung sebanyak 525 ekor untuk 3 (tiga) kontrol, 3 (tiga) perlakuan dan 6 (enam) kali pengulangan dengan masing-masing pengulangan membutuhkan lalat sebanyak 25 ekor, teknik pengambilan sampel secara random sampling, dan teknik pengumpulan data dengan menghitung presentase jumlah lalat yang tertolak serta mengukur suhu dan kelembaban udara ruangan, lama pengamatan 60 menit yang diamati setiap menit.

Penelitian dilakukan dengan 3 (tiga) perlakuan yaitu ekstrak daun jeruk nipis (Citrus aurantifolia) dalam bentuk lilin aromatik terhadap jumlah lalat rumah (Musca domestica) yang tertolak, dengan konsentrasi 0,4\%, 0,6\%, 0,8\%, dan kontrol yang tidak menggunakan ekstrak daun jeruk nipis.

Analisis data dilakukan dengan menggunakan uji Kruskal-Wallis dan $T$ Test menggunakan program SPSS v.18 
untuk mengetahui perbedaan yang bermakna berbagai konsentrasi ekstrak daun jeruk nipis terhadap jumlah lalat rumah (Musca domestica) yang tertolak.

\section{HASIL}

Suhu dan kelembaban udara ruangan selama penelitian pada tanggal 25 Meni 2017 pada pukul $07.00-08.00$, $08.15-09.15$, dan $09.300-10.30$ WIB diperoleh suhu di ruangan perlakuan berkisar antara $23,3^{\circ} \mathrm{C}$ sampai $29,4^{\circ} \mathrm{C}$ dan kelembaban di ruangan perlakuan berkisar antara $64 \%$ sampai $78 \%$ sedangkan suhu di ruangan kontrol berkisar antara $23,3^{\circ} \mathrm{C}$ sampai $29,1^{\circ} \mathrm{C}$ dan kelembaban di ruangan kontrol berkisar antara $64 \%$ sampai $77 \%$ (Tabel 1.)

Rata-rata jumlah lalat rumah (Musca domestica) yang hinggap pada kontrol yaitu 756 ekor lalat, rata-rata jumlah lalat yang hinggap pada konsentrasi 0,4\% yaitu 136 ekor lalat, pada ekstrak daun jeruk nipis dengan konsentrasi $0,8 \%$ rata-rata jumlah lalat yang hinggap yaitu 102 ekor lalat, dan pada ekstrak daun jeruk nipis dengan konsentrasi $0,8 \%$ rata-rata jumlah lalat yag hinggap yaitu 54 ekor lalat (Tabel 2.

Tabel 1. Data Hasil Pengukuran Suhu dan Kelembaban Udara Ruangan

\begin{tabular}{cccccc}
\hline \multirow{3}{*}{ Pengulangan } & Waktu & \multicolumn{4}{c}{ Hasil Pengukuran } \\
\cline { 3 - 5 } & Pengukuran & Ruangan & Ruangan & \multicolumn{2}{c}{ Kelembababan Udara (\%) } \\
\cline { 3 - 5 } & & Kontrol & Perlakuan & Kontrol & Ruangan \\
& & $23,2-26,6$ & $23,3-26,8$ & $64-78$ & $64-77$ \\
\hline 1 dan 2 & $07.00-08.00$ & $25-27$ & $25-27,1$ & $65-75$ & $62-76$ \\
3 dan 4 & $08.15-09.15$ & $25-29,1$ & $25,1-29,4$ & $65-74$ & $66-74$ \\
\hline 5 dan 6 & $09.30-10.30$ & $23,2-29,1$ & $23,3-29,4$ & $64-78$ & $64-77$ \\
\hline
\end{tabular}

Tabel 2. Hasil Pengamatan Jumlah Lalat Rumah yang Hinggap

\begin{tabular}{ccccc}
\hline \multirow{2}{*}{ Pengulangan } & \multicolumn{5}{c}{ Jumlah Lalat Rumah yang Hinggap pada Masing-Masing } \\
& Kontrol & $0,4 \%$ & $0,6 \%$ & $0,8 \%$ \\
\cline { 2 - 5 } & 765 & 184 & 108 & 34 \\
2 & 765 & 126 & 130 & 89 \\
3 & 747 & 129 & 99 & 139 \\
4 & 747 & 164 & 131 & 9 \\
5 & 754 & 67 & 27 & 19 \\
6 & 754 & 147 & 120 & 35 \\
\hline Jumlah & 4532 & 817 & 615 & 325 \\
\hline Rata-rata & 756 & 136 & 102 & 54 \\
\hline
\end{tabular}

Untuk mengetahui perbedaan yang bermakna berbagai konsentrasi dari ekstrak daun jeruk nipis (Citrus aurantifolia) dilakukan analisis KruskalWalis. Hasil significancy (p) dengan angka $0,045<\alpha(0,05)$ maka secara statistik terdapat perbedaan yang bermakna berbagai konsentrasi ekstrak daun jeruk nipis (Citrus aurantifolia) dalam bentuk lilin pada konsentrasi $0,4 \%, 0,6 \%$ dan $0,8 \%$ terhadap jumlah lalat rumah (Musca domestica) yang tertolak setelah dikontakan selama 1 jam.

\section{PEMBAHASAN}

Terjadi peninggkatan persentase jumlah lalat rumah yang tertolak seiring peningkatan konsentrasi ekstrak daun jeruk nipis dalam bentuk lilin aromatik yaitu semakin tinggi ekstrak konsentrasi semakin banyak jumlah lalat rumah yang tertolak. Karena bahan aktif dalam ekstrak yaitu minyak atsiri pun 
meningkat seiring dengan peningkatan konsentrasi.

Menurut Iskandar, 1985 (dalam Martini et al, 2002) minyak atsiri termasuk salah satu standar repellent yang digunakan untuk mencegah gigitan arthropoda. Minyak atsiri memiliki kandungan golongan terpenoid, hidrokarbon dan senyawa aromatik. ${ }^{9}$ Golongan terpenoid mengandung zat yang berfungsi sebagai repellent diantaranya adalah cineol, eugenol, limonene, terpinolen, citronellol, champor, dan timol. ${ }^{10}$

Senyawa-senyawa kimia minyak atsiri tumbuhan terbukti mempengaruhi aktivitas lokomotor yang merupakan aktivitas gerak. Komponen aroma minyak atsiri berinteraksi cepat dengan sistem syaraf pusat dan langsung merangsang pada sistem olfactory, kemudian akan menstimulasi syarafsyaraf otak dibawah keseimbangan korteks serebral. ${ }^{10}$

Lilin aromatik ekstrak daun jeruk nipis dapat digunakan secara langsung untuk menurunkan populasi lalat karena adanya aroma dari ekstrak daun jeruk nipis tersendiri yang mengganggu sistem saraf pusat lalat, sehingga lalat menjauhi area sekitar lilin. Mekanisme penolakan lalat rumah (Musca domestica) dengan menggunakan lilin ekstrak daun jeruk nipis tersebut melalui saluran pernapasan. Kandungan minyak atsiri dalam ekstrak daun jeruk nipis yang terbakar akan melayang di udara dalam bentuk partikel mikro, partikel tersebut masuk ke dalam

\section{SARAN}

Perlu dilakukan penelitian lebih lanjut mengenai ekstrak daun jeruk nipis dalam bentuk lilin aromatik untuk menolak jenis serangga lain dan

\section{DAFTAR PUSTAKA}

1. Rianto, Agus. 2011. Aplikasi Metodoogi Penelitian Kesehatan. saluran pernafasan lalat rumah melalui trachea.

Senyawa aktif dalam minyak atsiri yang terbakar dalam lilin berperan sebagai penurun nafsu makan dan penghalau yang mengakibatkan hama atau serangga enggan mendekati lingkungan sekitar zat tersebut menurut Buchbauer, 2010 (dalam Dwitya, 2015). Dengan demikian serangga yang tidak menyenani racun yang bersifat repelen dapat secepatnya menghindari sasaran walaupun telah diberi umpan.

\section{KESIMPULAN}

Persentase jumlah lalat rumah yang tertolak pada masing-masing konsentrasi ekstrak daun jeruk nipis dalam bentuk lilin aromatik yaitu pada konsentrasi $0,4 \%$ ekstrak daun jeuk nipis dalam bentuk lilin aromatik persentase jumlah lalat rumah yang tertolak sebesar 81,98\%, pada konsentrasi $0,6 \%$ ekstrak daun jeruk nipis dalam bentuk lilin aromatik persentase jumlah lalat rumah yang tertolak sebesar $86,43 \%$, dan pada konsentrasi $0,8 \%$ ekstrak daun jeruk nipis dalam bentuk lilin aromatik persentase jumlah lalat rumah yang tertolak sebesar $92,82 \%$.

Terdapat perbedaan yang bermakna antara konsentrasi ekstrak daun jeruk nipis (Citrus aurantifolia) dalam bentuk lilin aromatik terhadap jumlah lalat rumah (Musca domestica) yang tertolak berdasarkan uji KruskalWallis dengan nilai $P \leq \alpha(0,045 \leq 0,05)$.

diharapkan masyarakat dapat menggunakan ekstrak daun jeruk nipis dalam bentuk lilin aromatik untuk menolak kehadiran lalat rumah, terutama di warung-warung makanan.

Yogyakarta. Muha Medika. Cetakan II.

2. Hastutiek, poedji. 2013. potensi musca domestica linn. sebagai vektor beberapa penyakit. jurnal 
kedokteran brawijaya, vol. xxiii, no. 3, desember 2007. (online), http://www.jkb.ub.ac.id/index.php/jk b/article/viewfile/298/285 diakses pada tanggal 31 desember 2018.

3. Dirjen P2M \& PL. Depkes RI, 2001. (dalam Abdullah, Khonsa. 2014). Pengaruh Berbagai Konsentrasi Larutan Daun Cengkeh (Syzigium aromaticum) terhadap Jumlah Lalat Hijau (Chrysomya megacephala) yang Hinggap Selama Proses Penjemuran Ikan Asin. Bansung : Karya Tulis IImiah.

4. Naria E. 2005. Insektisida nabati untuk rumah tangga. Info kesehatan Masyarakat Fakultas Kesehatan Masyarakat USU, Medan 9(1).

5. Murdani, Rina. 2014. Keefektifan Daya Bunuh Ekstrak Daun Jeruk Nipis (Citrus auranifolia) terhadap Kematian Larva Nyamuk Aedes aegypti Instar III. Surakarta : Skripsi. 1-3.
6. Wulandari, Mutiara Juni, dkk. 2016. Jenis-Jenis Komponen Minyak Atsiri yang Diisolasi dari Daun Citrus aurantifolia dan Citrus nobilis. Jurnal Biologi dan Pembelajarannya (JB\&P). e-ISSN: 2406 - 8659. 3.

7. Kardinan, A. 2002. Pestisida Nabati. Penebar Swadaya. Jakarta

8. Kartika dkk. 2014. Pemanfaatan Limonen dari Kulit Jeruk Nipis dalam Pembuatan Lilin Aromatik Penolak Serangga. Bandung : Jurnal.

9. Iskandar. 1985. (dalam Martini, dkk. 2002). Efektifitas (Daya Tolak) dari Berbagai Jenis Daun Jeruk (Citrus sp.) terhadap Kontak Nyamuk Aedes Aegypti. Laporan Penelitian. No. $120 /$ J07. Semarang.

10. Rilianti, Dwitya. 2015. Daya Tolak Ekstrak Ethanol Daun Pandan Wangi (Pandanus amaryllifolius) Sebagai Repellent Terhadap Nyamuk Aedes Aegypti. Lampung. Skripsi. 